\title{
The Influence of Polysulfide Solvent on the Performance of
} Cadmium Sulfide Sensitized Zirconium Dioxide-Based Quantum Dots

\author{
Ravi V. Ingle, Abhijit T. Supekar, Vikram P. Bhalekar*, Bikram Prasad and Habib M. Pathan*
}

\begin{abstract}
The effect of two different types of polysulfide solvents (i.e., distilled water and methanol) was investigated for zirconium dioxide $\left(\mathrm{ZrO}_{2}\right)$ based quantum dots sensitized solar cells (QDSSCs). This was mainly depending upon how easily the injection of electrons in the conduction band of $\mathrm{CdS}$ particles to the $\mathrm{ZrO}_{2}$ photoanode. Compared to that with methanol solvent-based polysulfide, distilled water-based polysulfide $\left(\mathrm{S}^{2-} / \mathrm{S}_{\mathrm{n}}{ }^{2-}\right)$ electrolytes have efficient electron transportation characteristics at the interface of $\mathrm{ZrO}_{2} / \mathrm{CdS}$ photoanode and carbon counter electrode. Solar cell efficiency using distilled water-based polysulfide for $\mathrm{ZrO}_{2} / \mathrm{CdS}$ reaches $1 \%$. The catalytic reaction due to incorporation of polysulfide solvents positively affects the solar cell performance as evident from Nyquist plots. Distilled water-based polysulfide electrolyte has significant impacts on the overall performance of QDSSCs.
\end{abstract}

Keywords: Zirconium dioxide; Cadmium sulfide; Electron transport; Polysulfide.

Received: 13 April 2020; Accepted: 26 August 2020.

Article type: Research article.

\section{Introduction}

Last two decades, several metal oxides and chalcogenide semiconductors such as titanium dioxide $\left(\mathrm{TiO}_{2}\right),{ }^{[1]}$ zinc oxide, ${ }^{[2]}$ tungsten oxide, ${ }^{[3]}$ zinc sulfide $^{[4]}$ and cadmium sulphide ${ }^{[5]}$ were applied for the solar cells, supercapacitors and quantum dots application perspective. Zirconium dioxide or zirconia $\left(\mathrm{ZrO}_{2}\right)$ is one of the newly explored metal oxides used as photoanodes in dye-sensitized solar cells (DSSCs) and quantum dots (QD) SSCs. ${ }^{[6]}$ However, $\mathrm{ZrO}_{2}$ shows prolonged stability for QD based solar cells compared to the dye-based SCs even at the high temperature of oxidation..$^{[7]}$

The reported band gaps of $\mathrm{ZrO}_{2}$ can be stretched between 3.35 to $5.11 \mathrm{eV}$ depending upon the synthesis process and phase of the crystal structure. ${ }^{[8]}$ The reported porous structure and crystallinity nature of $\mathrm{ZrO}_{2}$ provide surface sites for the reactants to satisfy all requirements for the light-harvesting photoanodes. ${ }^{[9]}$ On account of all these characteristics, $\mathrm{ZrO}_{2}$ becomes a new class of photoelectrode for photovoltaic

Advanced Physics Laboratory, Department of Physics,

Savitribai Phule Pune University, Pune - 411007.

*E-mail:pathan@physics.unipune.ac.in (H.M. Pathan),

bhalekarvp@gmail.com (V.P.Bhalekar). applications. ${ }^{[10,11]}$ Due to wide bandgap nature, $\mathrm{ZrO}_{2}$ is capable of absorbing only ultraviolet (UV) range of photons; however, these are only a small fraction of the solar spectrum. For harvesting visible light, it is necessary to extend their absorption range in the visible regions. Thus, it needs to combine two semiconductors films, i.e., one for UV light absorber $\left(\mathrm{ZrO}_{2}\right)$ and one with the visible light absorber or sensitizers $(\mathrm{CdS})$. Among the sensitizers, $\mathrm{CdS}$ is one of the efficient QD sensitizers for the application of QDSSCs because of its suitable bandgap (2.25 to $2.42 \mathrm{eV}$ depending upon the synthesis process and phase of the crystal structure) for harvesting broad visible range of photons from the solar spectrum. ${ }^{[12-14]}$

Although $\mathrm{ZrO}_{2}$ is a direct band gap metal oxide having an optical band gap around $5.11 \mathrm{eV}$, it is transparent for the visible range of photons, possesses high refractive index, good adhesion to the substrates and exhibits high thermal stability. ${ }^{[15-18]}$ After the deposition of CdS QDs over $\mathrm{ZrO}_{2}$ photoanode, a boundary layer in between energy levels of CdS QDs and conduction band of $\mathrm{ZrO}_{2}$ is formed. ${ }^{[19]}$ For easy transition or injection of electrons, the conduction band edge of photoanodes must be at the lower level than the conduction band edge of sensitizers or window materials. However, in this case of $\mathrm{ZrO}_{2} / \mathrm{CdS}$, the conduction band edge of $\mathrm{ZrO}_{2}$ is almost 
at the same level of the conduction band of $\mathrm{CdS}$, resulting in the injection of electrons or smooth transition of electrons from the conduction band of CdS into the conduction band edge of $\mathrm{ZrO}_{2}{ }^{[20]}$ Therefore, there is little probability for electrons to get transition smoothly from the conduction band of CdS into the conduction band edge of $\mathrm{ZrO}_{2}$.

For the $\mathrm{ZrO}_{2} / \mathrm{CdS}$ based QDSSC, two types of CdS QD or sensitizers were grown by chemical route over $\mathrm{ZrO}_{2}$ films. Apart from these, two different solvents were used for the preparation of polysulfide i.e., distilled water and methanol. In the current study, Nyquist, Bode plots and equivalent circuits were used to analyze the role of polysulfide electrolytes for the performance of solar devices and their electron transport properties and the mechanism of QDSSC. Polysulfide electrolyte ${ }^{[21]}$ is a well-known electrolyte for QDSSC because its redox couple $\left(\mathrm{S}^{2-} / \mathrm{S}_{\mathrm{n}}{ }^{2-}\right)$ can stabilize most $\mathrm{QDs}$.

\section{Experiments}

Zirconia powder, ethyl cellulose, terpineol, acetyl acetone, cadmium sulphate, thiourea, ammonium hydroxide, aqueous ammonia, sulfur powder, and sodium sulfide were purchased from SRL Chemicals Ltd. India. Methanol and ethanol were purchased from C. H. Fine Chemicals Co. Ltd. and used as received without any further purification.

\subsection{Synthesis of CdS nanoparticles}

The synthesis technique of colloidal CdS particles, bulk CdS and CdS QDs is mentioned in our previous published article. ${ }^{[21]}$ The three different types of CdS quantum dots are named as type- a, type-b and type-c, which contains $0.05 \mathrm{M}$ cadmium sulfate, $0.05 \mathrm{M}$ thiourea, and $20 \%$ ammonium hydroxide at room temperature. Excess aqueous ammonia $\left(\mathrm{NH}_{4} \mathrm{OH}\right)$ was added to the growth solution to attain $\mathrm{pH}$.

\subsection{Fabrication of $\mathrm{ZrO}_{2}$ photoanodes}

The $\mathrm{ZrO}_{2}$ powder and ethyl cellulose were grinded in mortar pastel by adding Terpineol solution, the assembly was maintained in an ultrasonication bath for 3 hrs. The acetyl acetone was added during the ultrasonication at room temperature. The slurry formed was pasted on the fluorine doped tin oxide (FTO) substrate by the doctor blade technique. The as synthesized type-a, type-b and type-c CdS nanoparticles were deposited on $\mathrm{ZrO}_{2}$ photoelectrode using a chemical bath deposition technique.

\subsection{Synthesis of polysulfide electrolyte}

A non-aqueous polysulfide redox electrolyte composed of $0.98 \mathrm{~g} \mathrm{Na}_{2} \mathrm{~S}$ in $22.5 \mathrm{~mL}$ methanol and $0.08 \mathrm{~g}$ sulfur powder in $5 \mathrm{~mL}$ ethanol solution is a mixed and grinded for $15 \mathrm{~min}$. Finally, polysulfide electrolytes were synthesized in two different types of solvents methanol and distilled water. In the methanol case, $0.98 \mathrm{~g}$ of sodium sulfide $\left(\mathrm{Na}_{2} \mathrm{~S}\right)$ was crushed using mortar pestle and $22.5 \mathrm{~mL}$ of methanol was used to form a solution. $0.08 \mathrm{~g}$ of sulfur powder with $5 \mathrm{~mL}$ of methanol was added into the resultant solution of $\mathrm{Na}_{2} \mathrm{~S}$ to form methanol based polysulphide electrolyte; whereas in the distilled water case, $0.78 \mathrm{~g}$ of $\mathrm{Na}_{2} \mathrm{~S}$ was dissolved in the $25 \mathrm{~mL}$ of distilled water, pallets of sodium hydroxide $(\mathrm{NaOH})$ and of sulfur powder, were crushed and added to the $\mathrm{Na}_{2} \mathrm{~S}$ solution to form the distilled water based polysulphide electrolyte.

The X-ray diffraction (XRD) (model: XRD, Rigaku"D/B max-2400", $\mathrm{Cu} \mathrm{K \alpha}, \lambda=1.54 \AA$ ) was used to determine the crystalline nature, phase, and crystallite size of $\mathrm{ZrO}_{2}$ films. and field emission scanning electron microscopy (FESEM) (Carl Zeiss, Merlin Compact) techniques were used for the structural and morphological properties of the samples, respectively. Optical absorption spectra is obained using UVVis spectrophotometer (JASCO V-670) in the wavelength range of 200-1000 nm and the Electrochemical Impedance Spectroscopy (EIS) studied by Potentiostat/Galvanostat (IVIUM Vertex model), whereas J-V characteristics were obtained from the 2420 Kethley Source meter.
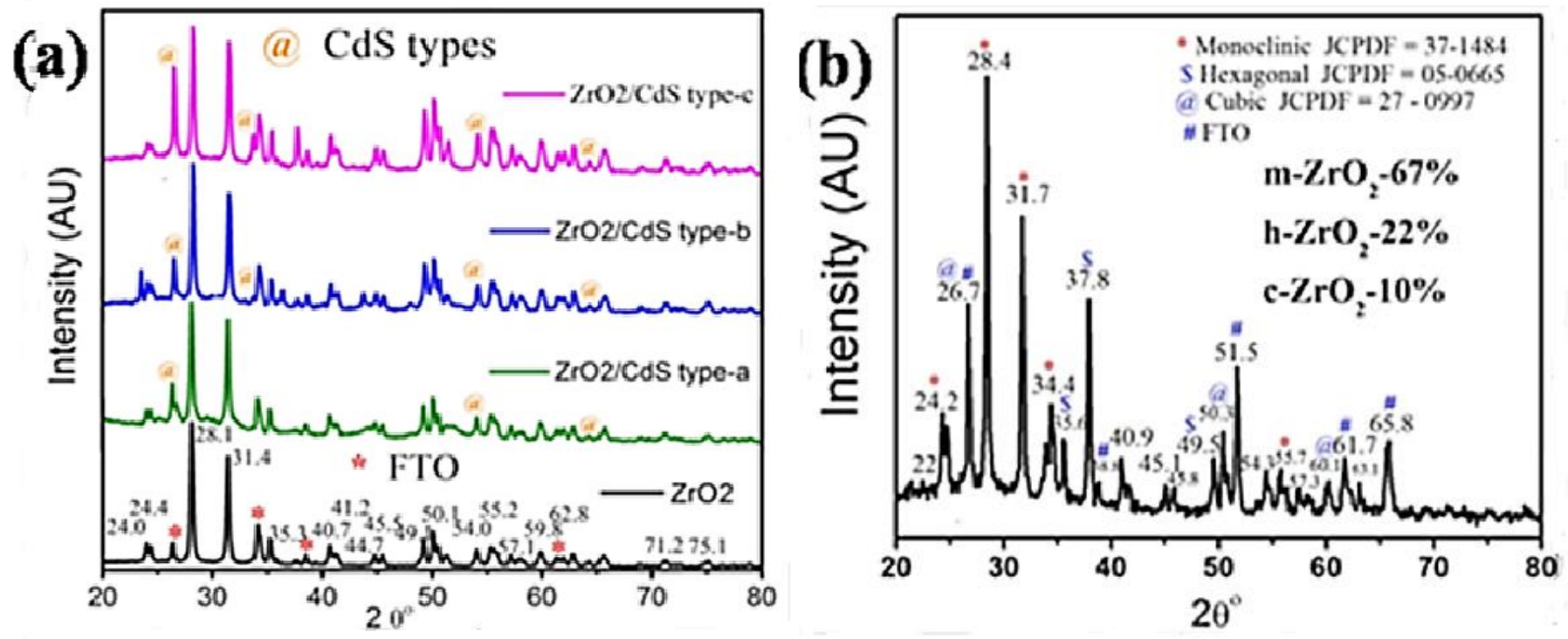

Fig. 1 XRD patterns for (a) CdS sensitized $\mathrm{ZrO}_{2}$ photoanodes and (b) $\mathrm{ZrO}_{2}$ film on FTO substrate. 


\section{Results and Discussion}

\subsection{Structural properties}

The XRD patterns of $\mathrm{CdS}, \mathrm{ZrO}_{2}$, and $\mathrm{ZrO}_{2}$ based QDSSC sensitized by $\mathrm{CdS}$ are shown in Fig. 1(a). The observed diffraction peaks are corresponding to 24.2(011), 28.4(111), $31.7(220)$ and $34.4^{\circ}(221)$ for the monoclinic $(\mathrm{m})$ phase of $\mathrm{ZrO}_{2}$ confirmed by JCPDS card no. 37-1484. But 24.2, 34.4, $40.9,54.3$ and $55.7^{\circ}$ show doublet peaks with some other unknown peaks, which are the significant peaks assigned for $\mathrm{m}-\mathrm{ZrO}_{2}$, as shown in Fig. 1(b). The reported phase for this peak is due to $\mathbf{O}_{2}$-deficient $\mathrm{ZrO}_{0.35}$ confirmed by JCPDS card no. 17-0385, space group P6322 having the hexagonal phase not shown in Fig. $1 .^{[8]}$ The characteristic peaks along (111), and (200) planes at $2 \theta$ values are at 26.7, 50.3 and $60.1^{\circ}$ corresponding to CdS with the cubic crystal structure (JCPDS Card No. 27-0997). However, the characteristic peaks at 35.3, 50.1 and $59.8^{\circ}$ having lattice planes (110), (200) and (211) respectively confirmed the tetragonal phase of $\mathrm{ZrO}_{2}$ (JCPDS card No. 05-0665). The crystal phase purity shows that monoclinic, tetragonal and cubic phases are $67 \%, 22 \%$, and $10 \%$ respectively whereas the remaining $1 \%$ is due to $\mathbf{O}_{2^{-}}$ deficient $\mathrm{ZrO}_{0.35}$. The diffraction peaks for the $\mathrm{m}-\mathrm{ZrO}_{2}$ show the highest intensities compare to $\mathrm{c}-\mathrm{ZrO}_{2}$ and $\mathrm{t}-\mathrm{ZrO}_{2}$ which represents $\mathrm{m}-\mathrm{ZrO}_{2}$ which is more crystalline nature than c$\mathrm{ZrO}_{2}$ and $\mathrm{t}-\mathrm{ZrO}_{2}$ as shown in Fig. 1 (b).

\subsection{Optical properties}

The deposition of three types of colloidal CdS particles over $\mathrm{ZrO}_{2}$ photoanode is carried out using a chemical method. The band gap $\left(\boldsymbol{E}_{g}\right)$ for CdS type-a, b and c are 2.38, 2.49 and 2.61 $\mathrm{eV}$ respectively, as shown in Fig. 2(a). The $\boldsymbol{E}_{\boldsymbol{g}}$ for $\mathrm{ZrO}_{2}$ photoanode is calculated as $5.11 \mathrm{eV}$, the corresponding $\boldsymbol{E}_{\boldsymbol{g}}$ in the UV optical spectrum is at $240 \mathrm{~nm}$ as shown in Fig. 2(b).
But after depositing $\mathrm{Cds}$ on $\mathrm{ZrO}_{2}$, the corresponding $\boldsymbol{E}_{\boldsymbol{g}}$ for $\mathrm{CdS}-\mathrm{ZrO}_{2}$ film shows red shifts towards longer wavelengths as shown in Fig. 2(a). The thickness (d) of the $\mathrm{ZrO}_{2}$ film is $\sim 10$ $\mu \mathrm{m}$. Hence despite $\mathrm{ZrO}_{2}$ is a wide band gap metal oxide, after the deposition of colloidal CdS particles as sensitizers or window materials, the combined $\mathrm{ZrO}_{2}$ and $\mathrm{CdS}$ gives typical metal oxide based like solar devices having better efficiency (PCE), fill factor $(\boldsymbol{F F})$, current density $\left(\boldsymbol{J}_{\boldsymbol{s c}}\right)$ and open circuit voltage $\left(\boldsymbol{V}_{\boldsymbol{o c}}\right)$, which have not been reported yet in the literature.

Fig. 3 shows the SEM images of the obtained films. The images were obtained at a various magnification of $\mathrm{x} 3000, \mathrm{x} 10$, 000 and $\mathrm{x} 30,000$. SEM images for bared $\mathrm{ZrO}_{2}$ photoanode $\mathrm{a}_{1}$ to $a_{3}$; whereas $b_{1}$ to $b_{3}$ for $\mathrm{ZrO}_{2} / \mathrm{CdS}$ type-a to type-c respectively show the comparable morphology. $\mathrm{ZrO}_{2}$ film structure is a granular type having macroporous morphology ( $>50 \mathrm{~nm}$ ). After the deposition of CdS, type-b shows macroporous morphology having flakes as shown in $\left(\mathbf{b}_{2}\right)$. However, these flake shapes of macroporosity almost disappear in the case of type-c, hence in the $J-V$ measurement of $\mathrm{ZrO}_{2} / \mathrm{CdS}$ type-c based QDSSC, very low $\boldsymbol{J}_{\boldsymbol{s c}}, \boldsymbol{V}_{\boldsymbol{o c}}$ and hence low $\boldsymbol{F F}$ and efficiency are observed. The $J V$-measurement for $\mathrm{ZrO}_{2} / \mathrm{CdS}$ type-a gives an intermediate response between type-c and type-b, this could be verified from the intermediate porous morphology for $\mathrm{ZrO}_{2} / \mathrm{CdS}$ type-a film.

\subsection{Fabrication of solar cells}

The fabricated and chemical bath deposited CdS photoanodes $\left(\mathrm{CdS} / \mathrm{ZrO}_{2}\right)$ are used for the fabrication of solar cells, the carbon suites is used as counter electrode, which is fabricated on the FTO substrate.

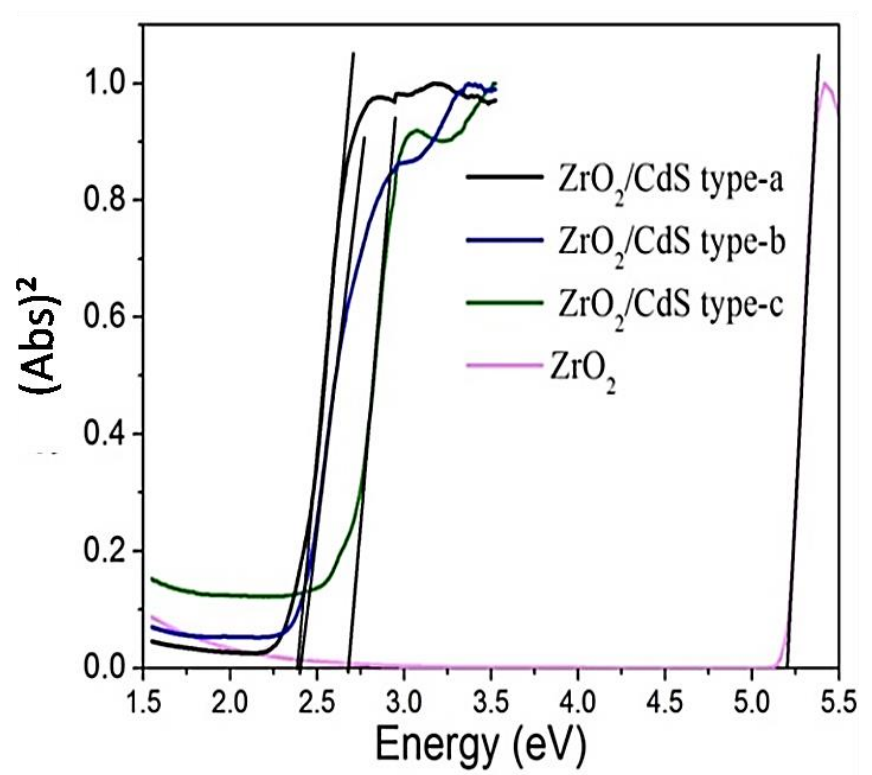

(b)

Fig. 2 UV-visible spectra for (a) colloidal CdS particles, it shows blue shifts for CdS type-b and c; and (b) $\mathrm{CdS} / \mathrm{ZrO}_{2}$ film, it also shows blue shifts for CdS type-a/ $\mathrm{ZrO}_{2}, \mathrm{CdS}$ type-b/ZrO 2 and $\mathrm{CdS}$ type-c/ $/ \mathrm{ZrO}_{2}$. 

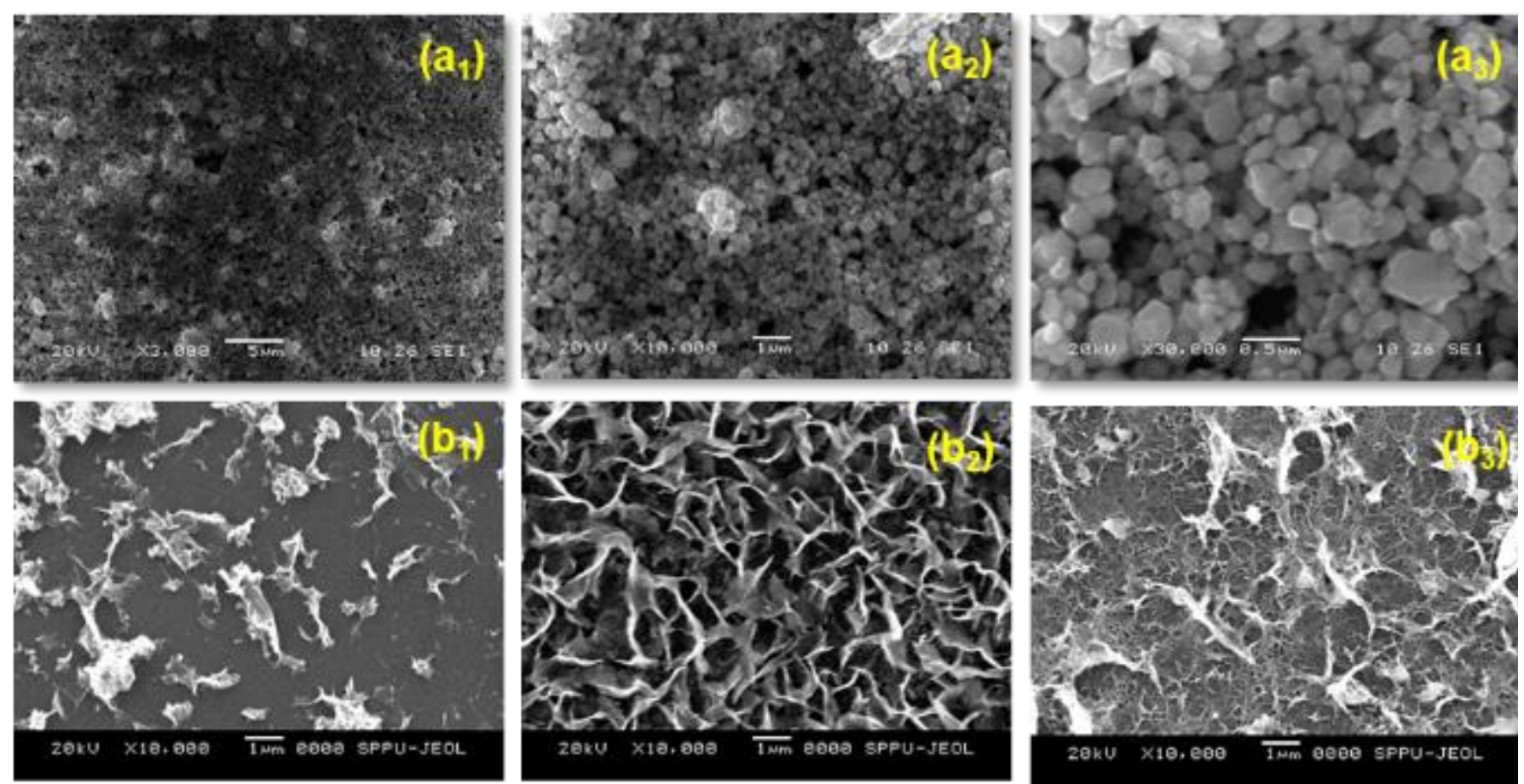

Fig. 3 SEM images of CdS, $\mathrm{ZrO}_{2}$ and $\mathrm{ZrO}_{2} / \mathrm{CdS}$ films: $\mathrm{a}_{1}-\mathrm{a}_{3}$ are for bared film of $\mathrm{ZrO}_{2}$. Bulk and nano size $\mathrm{CdS}$ particles deposited on $\mathrm{ZrO}_{2}$ films ( $\left.\mathbf{b}_{1}\right)$ for $\mathrm{ZrO}_{2} / \mathrm{CdS}$ type-a ( $\left.\mathbf{b}_{2}\right)$ for $\mathrm{ZrO}_{2} / \mathrm{CdS}$ type-b and ( $\left.\mathbf{b}_{3}\right)$ for $\mathrm{ZrO}_{2} / \mathrm{CdS}$ type-c.

\subsection{Performance measurement}

Table 1. Solar cell parameters for $\mathrm{ZrO}_{2}$ based QDSSC where $\mathrm{CdS}$ type-a and type-b used for the sensitization (methanol based electrolyte) $\left(30 \mathrm{~mW} / \mathrm{cm}^{2}\right)$.

\begin{tabular}{cccccc}
\hline $\begin{array}{c}\mathrm{ZrO}_{2} / \mathrm{CdS} \\
\text { based } \\
\text { QDSSCs }\end{array}$ & $\begin{array}{c}\text { Open circuit } \\
\text { voltage } \\
V_{o c} \\
(\mathrm{~V})\end{array}$ & $\begin{array}{c}\text { Current } \\
\text { density, } \\
\mathrm{J}_{\mathrm{sc}} \\
\left(\mathrm{mA} / \mathrm{cm}^{2}\right)\end{array}$ & $\begin{array}{c}\text { Fill } \\
\text { factor, } \\
\mathrm{FF}\end{array}$ & $\begin{array}{c}\text { Metastable } \\
\text { state, } \\
\tau_{\mathrm{e}}(\mathrm{ms})\end{array}$ & $\begin{array}{c}\text { PCE } \\
(\%)\end{array}$ \\
\hline For type-a & 0.38 & 0.31 & 0.15 & 0.79 & 0.058 \\
For type-b & 0.55 & 0.55 & 0.21 & 4.37 & 0.212 \\
For type-c & 0.055 & 0.03 & 0.23 & 0.05 & 0.006 \\
\hline
\end{tabular}

The methanol-based polysulfide electrolyte shows that the current densities (Jsc) for $\mathrm{ZrO}_{2}-\mathrm{CdS}$ type-a, $\mathrm{b}$ and $\mathrm{c}$ are 0.31 , 0.55 and $0.03 \mathrm{~mA} / \mathrm{cm}^{2}$, whereas open circuit voltage $\left(\mathrm{V}_{\mathrm{oc}}\right)$ are $0.38,0.55$ and $0.06 \mathrm{~V}$ respectively. PCE for CdS-type-b coated $\mathrm{ZrO}_{2}$ solar device is $0.21 \%$ which is greater among the $\mathrm{CdS}$ type-a and c. Only CdS type-b is compatible with mesoporous structure of $\mathrm{ZrO}_{2}$. Excited states of CdS type-a (Bulk) are not at the same level with conduction band of $\mathrm{ZrO}_{2}$. For type-c due to large band gap, only few electrons are diffused. Hence mesoporous $\mathrm{ZrO}_{2}$ is compatible with CdS type-b only.

Thus, the $P C E$ for CdS type-a and type-c are 0.06 and $0.006 \%$ respectively. Thus $\mathrm{ZrO}_{2}-\mathrm{CdS}$ type-c solar device shows a negligible PCE. However, the $F F$ for CdS type-c is 0.23 compare to CdS type-a (0.15) and type-c (0.21). Current densities for CdS type-a and b are noticeable, 0.31 and 0.55 $\mathrm{mA} / \mathrm{cm}^{2}$ respectively. The solar cell parameters for methanolbased electrolyte are shown in Fig. 4 and are summarized in Table 1. It is observed that the $J_{s c}, V_{o c}$, and $\eta$ initially increased and then decreased with decreasing the size of colloidal CdS particles. For distilled water-based polysulfide electrolyte, the $J_{S C}$ is higher for $\mathrm{ZrO}_{2}-\mathrm{CdS}$ type-b compared to CdS type-a and CdS type-c. It is also found that the $F F$ for type-b (0.34) also shows a better performance than that for CdS type-a $(0.30)$ and CdS type-c (0.24). Since not only the solar cell parameters but the stability for distilled water-based electrolyte are able to retain prolonged electron life time compared to the methanol based electrolyte.

Table 2. Solar cell parameters for $\mathrm{ZrO}^{2}$ based QDSSC where CdS type-a and type-b used for the sensitization (dw electrolyte) (30 $\left.\mathrm{mW} / \mathrm{cm}^{2}\right)$.

\begin{tabular}{|c|c|c|c|c|c|}
\hline $\begin{array}{c}\mathrm{ZrO}_{2} / \mathrm{CdS} \\
\text { based } \\
\text { QDSSCs }\end{array}$ & $\begin{array}{c}\text { Open circuit } \\
\text { voltage } \\
V_{o c} \\
\text { (V) }\end{array}$ & $\begin{array}{c}\text { Current } \\
\text { density, } \\
\mathrm{J}_{\mathrm{sc}} \\
\left(\mathrm{mA} / \mathrm{cm}^{2}\right)\end{array}$ & $\begin{array}{c}\text { Fill } \\
\text { Factor, } \\
\text { FF }\end{array}$ & $\begin{array}{c}\text { Metastable } \\
\text { state, } \\
\tau_{\mathrm{e}} \\
(\mathrm{ms})\end{array}$ & $\begin{array}{l}\text { PCE } \\
(\%)\end{array}$ \\
\hline For type-a & 0.77 & 0.89 & 0.30 & 13 & 0.68 \\
\hline For type-b & 0.61 & 1.44 & 0.34 & 9.55 & 1 \\
\hline For type-c & 0.44 & 1.78 & 0.24 & 1.66 & 0.62 \\
\hline
\end{tabular}

The solar cell parameters for distilled water based polysulfide electrolyte are summarized in Table 2 . It is observed that the $\boldsymbol{J}_{\boldsymbol{s} \boldsymbol{c}}, \boldsymbol{V}_{\boldsymbol{o c}}, \boldsymbol{\eta}$ initially increased and then decreased with decreasing the particle size of CdS from typea to type-c. The maximum PCE for CdS type-b is $1.0 \%$, which is higher than other two CdS type-a and type-c. The result of PCE and their variation clearly indicates that Polysulphide electrolyte gives a stable performance when used in solar cell devices. 

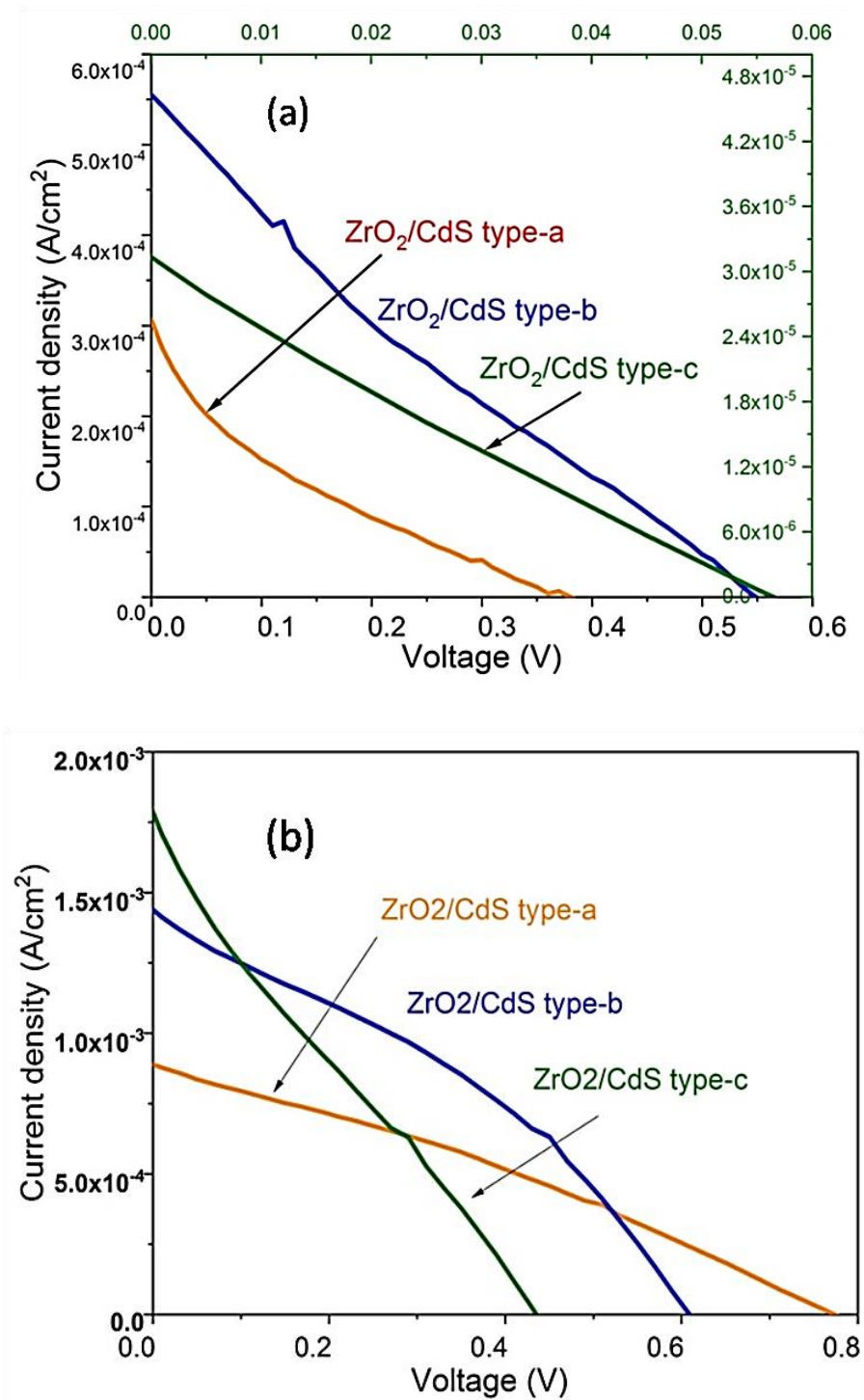

Fig. $4 \mathrm{~J}-\mathrm{V}$ characteristic of $\mathrm{CdS}$ sensitized $\mathrm{ZrO}_{2}$ photoanodes using (a) methanol based (b) DW based polysulfide electrolytes.

\subsection{Equivalent circuit Analysis}

The potentiostat/galvanostat is used to measure the photocurrent and photovoltage responses with respect to time and electrochemical impedance spectra. The solar devices were measured at $-1.0 \mathrm{~V}$ bias voltages under the dark condition having frequencies from $10^{-1}$ to $10^{5} \mathrm{~Hz}$ at $25{ }^{\circ} \mathrm{C}$. EIS measurement invokes the investigation of charge transport properties for $\mathrm{ZrO}_{2}$ based QDSSCs. For CdS type-b/ZrO based QDSSCs, there is a semicircle observed in the Nyquist plot. Equivalent circuit is fitted for this semicircle. Resistance is due to (1) electron transport, $\mathrm{S}^{2-}$ loses its electrons to the hole $\left(\mathrm{h}^{2+}\right)$ in valence or lowest unoccupied molecular orbital (LUMO) level of $\mathrm{ZrO}_{2} / \mathrm{CdS}$ QDs to become $\mathrm{S}$, this sulfur then takes electrons from sulfide ion $\left(\mathrm{S}_{\mathrm{n}-1}{ }^{2 \mathrm{n}}\right)$ whereas (2) at the counter electrode (CE), a reduction of $\mathrm{S}_{\mathrm{n}-1^{2 \mathrm{n}}}$ occurs with the gain of electrons from $\mathrm{S}_{\mathrm{n}-1}{ }^{2 \mathrm{n}}$ to the $\mathrm{S}_{\mathrm{n}}{ }^{2-}$. Thus, since redox reactions for regeneration and diffusions occur at the two interfaces, not all the electrons contributed to the redox process, some of them lose due to recombination at $\mathrm{ZrO}_{2} / \mathrm{CdS}$ and leakage at $\mathrm{CE}$, these losses of electrons created the Resistance (i.e., $R_{t r}$ or $R_{I}$ ) due to electron transport process.

For $\mathrm{ZrO}_{2} / \mathrm{CdS}$ type-b, the $R_{1}=618 \Omega$ is connected in the series with the charge transfer resistance, $R_{c l}=R_{2}=9.56 \mathrm{k} \Omega$ which is in parallel capacitor $C_{l}=0.57 \mu$ f. $R_{l}$ is due to the recombination process after the electrons are injected from CdS QDs to $\mathrm{ZrO}_{2}$ while $\boldsymbol{C}_{\boldsymbol{1}}$ acts as capacitive elements (constituent of reactance elements such as interface at conduction band and surface states of $\mathrm{ZrO}_{2}$ photoanodes). ${ }^{[22]}$ Because of the recombination process, all the electrons do not contributed to current densities, some of the electrons recombined with the holes. These recombined electrons are responsible for capacitive elements in the porous structure of $\mathrm{ZrO}_{2}$ photoanode. ${ }^{[23,24]}$

Semicircle in the lower frequency region shows a series combination of $R_{2}$ with $\mathrm{R}_{1} / / \mathrm{C}_{1}$ whereas the first semicircle represents the charge transfer at electrolyte/CE-FTO interface under higher frequency region shown in Fig. 6(a). This charge transfer also suffers from some electron losses at the interface of electrolyte/CE-FTO, which results in another charge transfer resistance, $R_{c t}{ }^{\prime}=R_{3}=650 \Omega$ for $\mathrm{ZrO}_{2}-\mathrm{CdS}$ type-b. Counter electrodes are the carbon electrodes. Since the capacitive element $\boldsymbol{C}_{\boldsymbol{1}}$ with $\boldsymbol{R}_{\boldsymbol{1}}$ is attributed to the recombination process at the interface of $\mathrm{ZrO}_{2} / \mathrm{CdS}$ and the electrolytes.

Higher $\boldsymbol{C}_{\boldsymbol{l}}$, in this case, indicates a higher related resistance to the recombination process. Another capacitance is observed at the interface of electrolyte and counter electrode, $C_{2}=1.63$ $\mu \mathrm{F}$ which is less than $C_{l} . C_{2}$ is due to a reduction at electrolyte/CE-FTO interface. The details for $\mathrm{ZrO}_{2}-\mathrm{CdS}$ typec are summarized in Table 3. Whereas details for distilled water-based polysulfide are summarized in Table 4 . Equivalent circuits fitted on Nyquist plots are shown in Fig. 7.

The metastable state for methanol-based electrolyte: $\mathrm{ZrO}_{2} / \mathrm{CdS}$ type-b has a longer electron lifetime $(0.7 \mathrm{~ms})$ compared to 0.12 and $0.008 \mathrm{~ms}$ for $\mathrm{ZrO}_{2} / \mathrm{CdS}$ type-a and type$\mathrm{c}$ based QDSSC respectively. Similar results were obtained for distilled water based electrolytes, but in this case $\boldsymbol{J}_{\boldsymbol{s} \boldsymbol{c}}, \boldsymbol{V}_{\boldsymbol{o c}}$ and $\boldsymbol{\eta}$ are better than methanol-based polysulfide as shown in Fig. 5 (b)and 6(b). Thus, the transition of electrons in $\mathrm{ZrO}_{2} / \mathrm{CdS}$ type-b for both the cases of methanol and distilled water-based electrolytes is in the lower frequency region compared to $\mathrm{ZrO}_{2} / \mathrm{CdS}$ type-a and type-c as explained in Scheme 1.

Higher capacitance $\left(\mathbf{C}_{\mathbf{1}}\right)$ in the range of micro Farad is due to electron recombination and regeneration process during the oxidation of polysulfide, holes in CdS QDs were replaced by electron from polysulfide whereas lesser capacitance $\left(\mathbf{C}_{2}\right)$ is due to reduction at the interface of electrolyte and counter electrode as shown in the Scheme $1{ }^{\left[{ }^{[25]}\right.}$ It is not necessary higher is the electron life time, but a better PCE. ${ }^{[26]}$ For both the cases of distilled water and methanol based polysulfide, electron life time in Bode phase plot is higher for $\mathrm{ZrO}_{2} / \mathrm{CdS}$ type-a as shown in of Fig. 4(b) and 5(b) but the PCE associated with CdS type-a is lower. 

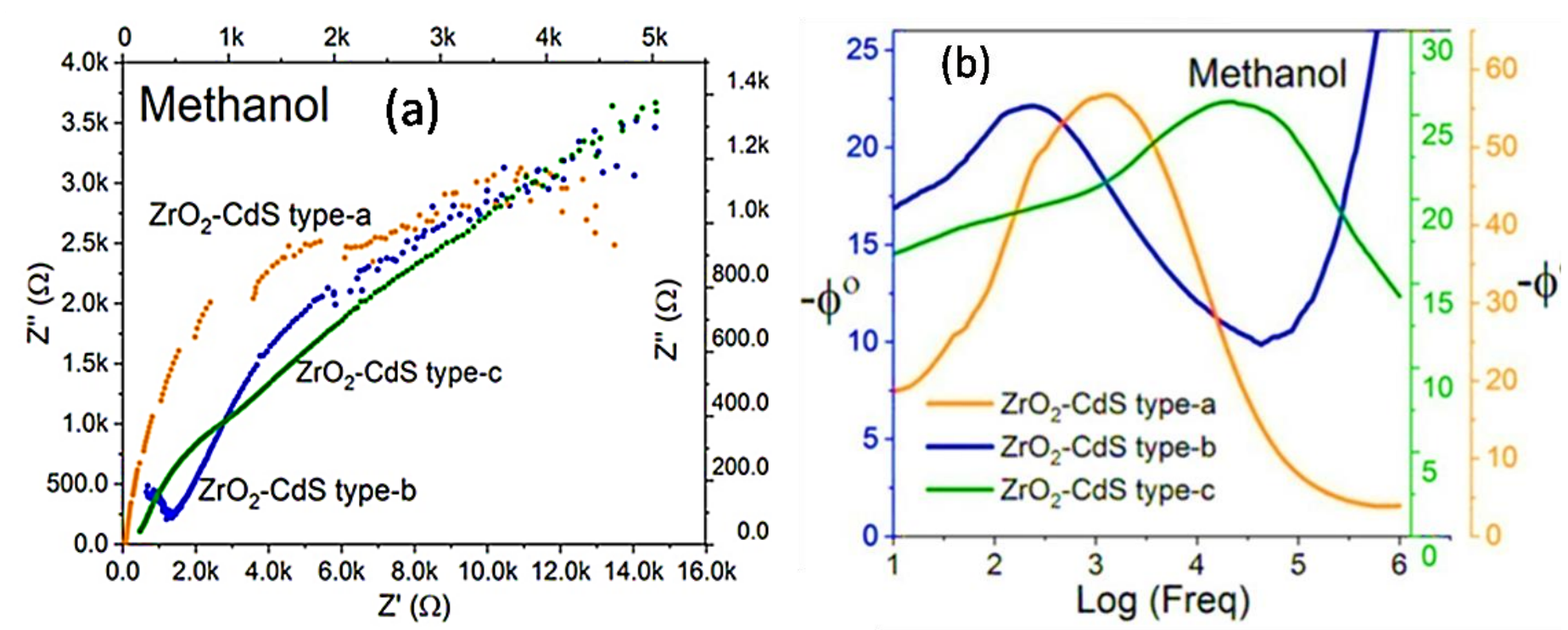

Fig. 5 (a) Bode plot and (b) Nyquist plot for $\mathrm{ZrO}_{2} / \mathrm{CdS}$ QDSSCs using methanol based polysulfide.

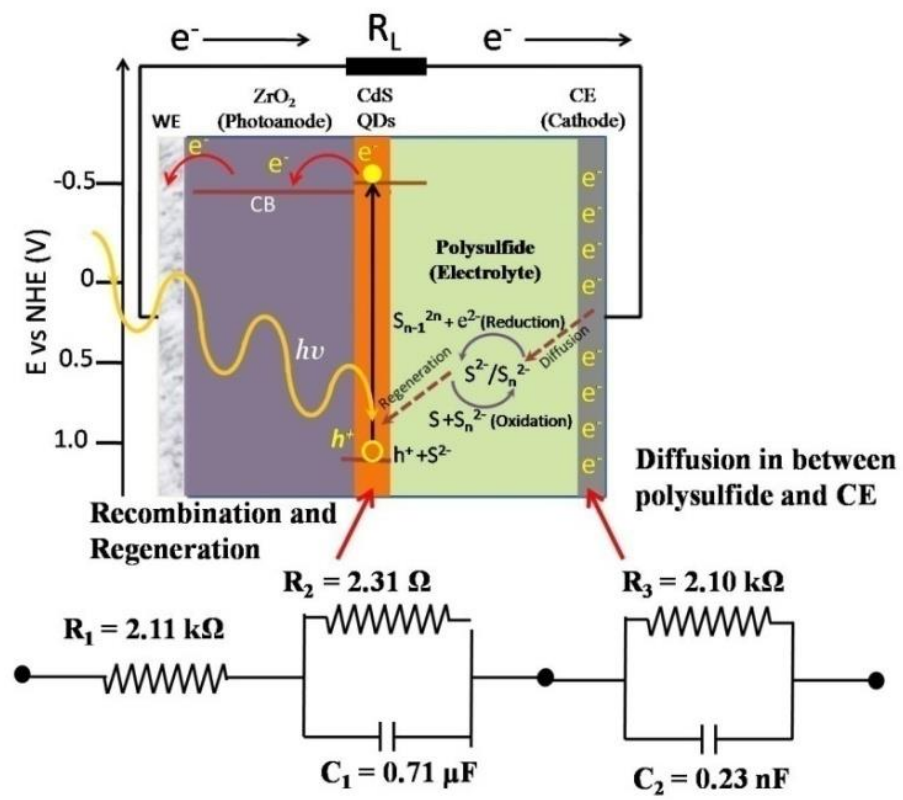

Scheme 1. Resistance and capacitance represent various processes within the solar device. Equivalent circuit represents the mechanism of QDSSC.

Enhanced electron lifetime with CdS type-a as a sensitizer over $\mathrm{ZrO}_{2}$, the photoanode material is probably due to lower concentration of oxygen vacancies in $\mathrm{ZrO} 2$ as compared to $\mathrm{TiO}_{2}$ and $\mathrm{ZnO} . \mathrm{ZrO}_{2}$ in this case possesses four crystal phases; monoclinic $(67 \%)$, tetragonal $(22 \%)$, cubic $(10 \%)$ and hexagonal $(1 \%)$. As reported earlier, monoclinic $\mathrm{ZrO}_{2}$ contained only $3 \%$ of oxygen vacancies. ${ }^{[8]}$ Thus in contact with $\mathrm{ZrO}_{2}$ photoanode with $\mathrm{CdS}$ colloidal particles, most of the electrons contributed to the electron transition process and very few got absorbed with the oxygen

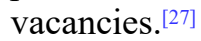

However, very few electrons in the energy levels of $\mathrm{CdS}$ QDs have been injected towards discrete energy levels of $\mathrm{ZrO}_{2}$ because of the band to band positions. These discrete energy levels are not compatible for electron transitions between $\mathrm{ZrO}_{2}$ and CdS QDs. ${ }^{[12]}$ Hence, most of the electrons from polysulfide are recombined within CdS QDs before being injected into $\mathrm{ZrO}_{2}$ photoanode. Unusual higher capacitance $\left(\mathrm{C}_{1}\right)$ for both the polysulfide cases represents this effect. Therefore, despite of higher electron lifetime, the highest PCE observed for $\mathrm{ZrO}_{2}-\mathrm{CdS}$ type-b is $1 \%$ less than that of $\mathrm{ZnO}$ and $\mathrm{TiO}_{2}-\mathrm{CdS}$ type-b (distilled water based polysulfide).

\subsection{Electron transport properties:}

Since the diffusion length $\left(\boldsymbol{D}_{l}\right)$ of an electron is the mean distance traveled by charged carriers from the point of generation to the recombination sites. ${ }^{[28]}$ It is observed for $\mathrm{CdS}$ type-a, $\boldsymbol{D}_{l}$ is higher than that of type-b and c. However, for the materials having more defects or surface states, the recombination rates will be higher. It may be seen that for $\mathrm{CdS}$ type-b/ZrO 2 , the $\boldsymbol{D}_{\boldsymbol{l}}$ is 1.29 and 3.23 for methanol and distilled water based polysulfide, respectively, inferring to the better performance for the later, as analyzed in Table 5 and 6 . These different values of $\boldsymbol{D}_{\boldsymbol{l}}$ show that polysulfide prepared in different solvents have different interactions with $\mathrm{CdS} / \mathrm{ZrO}_{2}$ photoanodes, hence $\boldsymbol{D}_{\boldsymbol{l}}$ is higher for methanol based polysulfide and lower in the case of distilled water based polysulphide for CdS type-a and type-c/ $\mathrm{ZrO}_{2}$ based QDSSCs. 

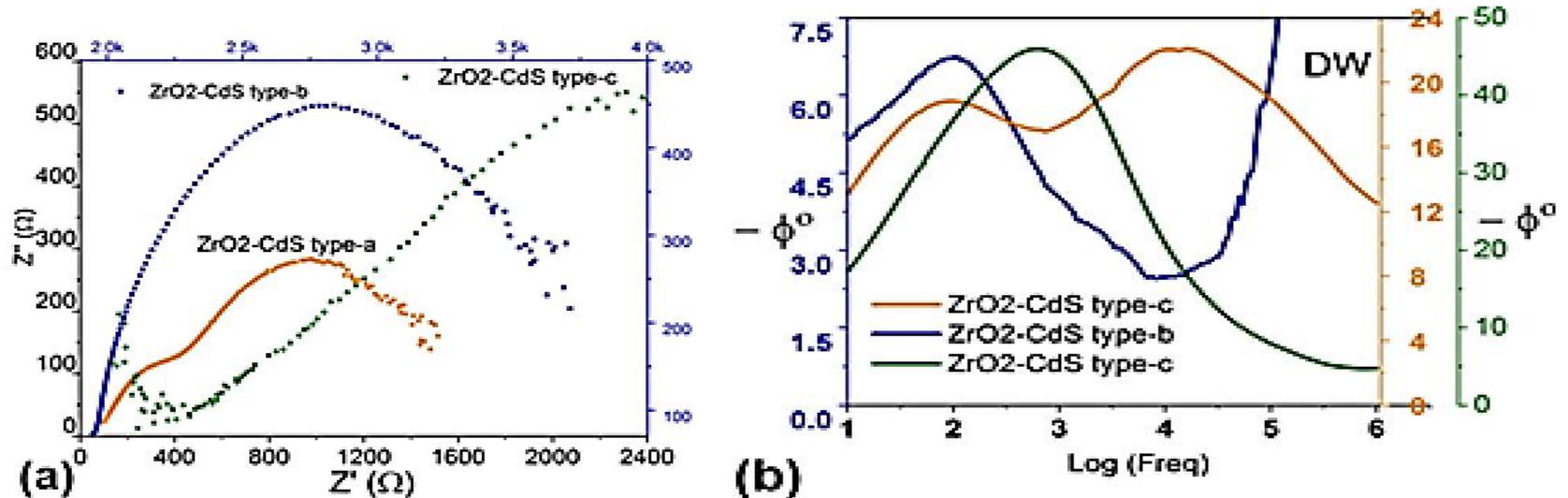

Fig. 6 (a) Nyquist plot and (b) Bode plot for $\mathrm{ZrO}_{2} / \mathrm{CdS}$ QDSSCs using DW based polysulfide.

Table 3. Details about Equivalent circuit parameters (Methanol based polysulfide).

\begin{tabular}{|c|c|c|c|c|c|c|}
\hline \multirow{3}{*}{ QDSSCs } & \multirow{3}{*}{$\begin{array}{c}\text { Electron transport } \\
\text { at } \begin{array}{c}\mathrm{ZrO}_{2} / \mathrm{CdS} / \mathrm{PS} \\
\text { and } \mathrm{PS} / \mathrm{CE}\end{array} \\
\mathrm{R}_{\mathrm{tr}}=\mathrm{R}_{2}(\Omega)\end{array}$} & \multicolumn{2}{|c|}{ Charge transfer } & \multirow{2}{*}{\multicolumn{2}{|c|}{ Capacitance }} & \multirow{3}{*}{$\begin{array}{c}\text { Effective } \\
\text { mean elec- } \\
\text { tron life time } \\
\tau_{\text {eff }}(\mathrm{ms})\end{array}$} \\
\hline & & \multirow{2}{*}{$\begin{array}{c}\mathrm{FTO} / \mathrm{ZrO}_{2} / \\
\mathrm{CdS}\end{array}$} & \multirow{2}{*}{$\begin{array}{c}\mathrm{CE} / \\
\mathrm{FTO} \\
\mathrm{R}_{\mathrm{ct}}{ }^{\prime}=\mathrm{R}_{3}(\Omega)\end{array}$} & & & \\
\hline & & & & $\mathrm{C}_{1}(\mu \mathrm{F})$ & $\mathrm{C}_{2}(\mu \mathrm{F})$ & \\
\hline CdS type-a & 618 & $9.56 \mathrm{k}$ & - & 0.57 & - & 0.79 \\
\hline CdS type-b & 854 & $1.43 \mathrm{k}$ & 650 & 4.70 & 1.63 & 4.37 \\
\hline CdS type-c & $1.24 \mathrm{~K}$ & $2.29 \mathrm{k}$ & $1.81 \mathrm{~K}$ & 1.12 & 0.00079 & 0.05 \\
\hline
\end{tabular}

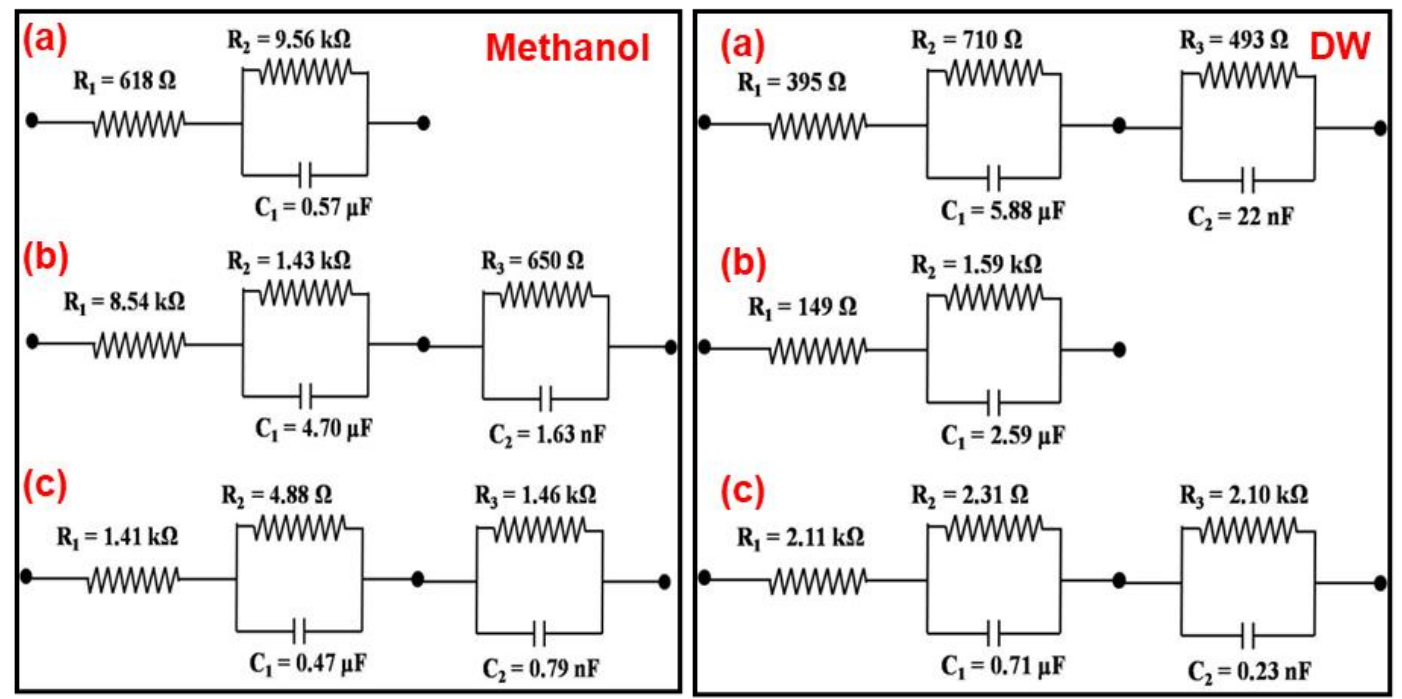

Fig. 7 Equivalent circuits for Nyquist plots: for methanol and DW based polysulfide. 
Table 4. Details about Equivalent circuit parameters (DW based polysulfide).

\begin{tabular}{|c|c|c|c|c|c|c|}
\hline \multirow{3}{*}{ QDSSCs } & \multirow{3}{*}{$\begin{array}{c}\begin{array}{c}\text { Electron transport } \\
\text { at } \mathrm{ZrO}_{2} / \mathrm{CdS} / \mathrm{PS} \\
\text { and } \mathrm{PS} / \mathrm{CE}\end{array} \\
\mathrm{R}_{\mathrm{tr}}=\mathrm{R}_{2}(\Omega)\end{array}$} & \multicolumn{2}{|c|}{ Charge transfer } & \multirow{2}{*}{\multicolumn{2}{|c|}{ Capacitance }} & \multirow{3}{*}{$\begin{array}{c}\text { Effective mean } \\
\text { electron life time } \\
\tau_{\text {eff }}(\mathrm{ms})\end{array}$} \\
\hline & & \multirow{2}{*}{$\begin{array}{c}\mathrm{FTO} / \mathrm{ZrO}_{2} / \\
\mathrm{CdS} \\
\mathrm{R}_{\mathrm{ct}}=\mathrm{R}_{1}(\Omega)\end{array}$} & \multirow{2}{*}{$\begin{array}{c}\mathrm{CE} / \\
\mathrm{FTO} \\
\mathrm{R}_{\mathrm{ct}}{ }^{\prime}=\mathrm{R}_{3}(\Omega)\end{array}$} & & & \\
\hline & & & & $\mathrm{C}_{1}(\mu \mathrm{F})$ & $\mathrm{C}_{2}(\mu \mathrm{F})$ & \\
\hline CdS type-a & 395 & 710 & 191 & 5.88 & 22 & 13 \\
\hline CdS type-b & 149 & $1.59 \mathrm{k}$ & - & 2.59 & - & 9.55 \\
\hline CdS type-c & $2.11 \mathrm{k}$ & $2.31 \mathrm{k}$ & $2.10 \mathrm{k}$ & 0.71 & 0.23 & 1.66 \\
\hline
\end{tabular}

Table 5. Electron transport properties of $\mathrm{ZrO}_{2} / \mathrm{CdS}$ based QDSSCs (Methanol based polysulfide).

\begin{tabular}{cccccc}
\hline QDSSCs & $\begin{array}{c}\text { Diffusion } \\
\text { length }\left(\mathrm{D}_{\mathrm{l}}\right) \\
\mu \mathrm{m}\end{array}$ & $\begin{array}{c}\text { Effective electron } \\
\text { diffusion co- } \\
\text { efficient } \\
\left.10^{-7} \mathrm{Dm}_{\mathrm{f}}\right) \mathrm{x}\end{array}$ & $\begin{array}{c}\text { Charge } \\
\text { collection } \\
\text { efficiency } \\
\left(\eta_{\mathrm{c}}\right) \%\end{array}$ & $\begin{array}{c}\text { Effective } \\
\text { electron } \\
\text { diffusion } \\
\text { length }\left(\mathrm{L}_{\mathrm{f}}\right) \mathrm{x} \\
\mu \mathrm{m}\end{array}$ & $\begin{array}{c}\text { Effective } \\
\text { electron } \\
\text { diffusion } \\
\text { time }\left(\tau_{\mathrm{D}}\right) \\
\mathrm{ms}\end{array}$ \\
\hline CdS type-a & 3.93 & 19.6 & 93 & 39.3 & 0.051 \\
CdS type-b & 1.29 & 0.38 & 40 & 12.9 & 2.61 \\
CdS type-c & 1.36 & 36.9 & 45 & 13.6 & 0.027 \\
\hline
\end{tabular}

Now the charge collection efficiency $\left(\boldsymbol{\eta}_{\boldsymbol{c}}\right)$ in the case of methanol-based polysulfide, for $\mathrm{CdS}$ type-a/ $\mathrm{ZrO} \mathrm{r}_{2}$ combination, shows $\boldsymbol{\eta}_{c} \sim 93 \%$, however, for CdS type-b and type-c, it is just $\boldsymbol{\eta}_{\boldsymbol{c}} \sim 40$ and $45 \%$ respectively. In the working principle of QDSSCs, the concentration gradients occur at the interface of (1) polysulfide/counter electrode and (2) $\mathrm{CdS} / \mathrm{ZrO}_{2}$ photoanodes/polysulfide. In the case of methanol based polysulfide, the effective electron diffusion co-efficient $\left(\boldsymbol{D}_{f}\right)$ for CdS type-c/ $/ \mathrm{ZrO}_{2}$ is about $36.9 \times 10^{-7} \mathrm{~cm}^{2} / \mathrm{s}$ compared to $\mathrm{CdS}$ type-a and type-b/Z $\mathrm{ZrO}_{2}$ combinations, which are 19.6 and $0.38 \times 10^{-7} \mathrm{~cm}^{2} / \mathrm{s}$, respectively as analyzed in Table 5 . Despite of higher $\boldsymbol{D}_{\boldsymbol{f}}$ for $\mathrm{CdS}$ type-c/ $/ \mathrm{ZO}_{2}$ combination, higher solar cell efficiency is shown for the $\mathrm{CdS}$ type-b/ $\mathrm{ZrO}_{2}$ as shown in Fig. 4.
However, in the case of distilled water based polysulfide, solar cell efficiency for $\mathrm{CdS}$ type-c/ $/ \mathrm{ZrO}_{2}$ combination supports the higher $\boldsymbol{D}_{f}$ values compared to other combinations of CdS type-a and CdS type-c as analyzed in Table 6. Similar results are true for effective electron diffusion length $\left(\boldsymbol{L}_{f}\right), 32.3$ $\mu \mathrm{m}$ for $\mathrm{CdS}$ type-b/ $/ \mathrm{ZrO}_{2}$ compared to other CdS types.

Finally, effective electron diffusion time $\left(\tau_{D}\right)$ is higher, $7.23 \mathrm{~ms}$ for $\mathrm{CdS}$ type-a/ $\mathrm{ZrO}_{2}$ combination not for CdS type$\mathrm{b} / \mathrm{ZrO}_{2}$. The reason behind the displayed all these electron transport properties is still being investigated as they are in correct correlation with the efficiency of QDSSCs. Kadam et al. calculated the electronic transport properties for DSSCs. ${ }^{[21]}$ Using these formulae, the calculated electron transport properties within QDSSCs are summarized in Tables 5 and 6. From the equivalent circuits $\mathrm{R}_{1}=\mathrm{R}_{\mathrm{ct}}$ and $\mathrm{R}_{2}=\mathrm{R}_{\mathrm{tr}}$.

Table 6. Electron transport properties of $\mathrm{ZrO}_{2} / \mathrm{CdS}$ based QDSSCs (DW based polysulfide).

\begin{tabular}{cccccc}
\hline QDSSCs & $\begin{array}{c}\text { Diffusion } \\
\text { length } \\
\left(\mathrm{D}_{\mathrm{l}}\right) \\
\mu \mathrm{m}\end{array}$ & $\begin{array}{c}\text { Effective } \\
\text { electron } \\
\text { diffusion co- } \\
\text { efficient } \\
\left(\mathrm{D}_{\mathrm{f}}\right) \times 10^{-7} \\
\mathrm{~cm}^{2} / \mathrm{s}\end{array}$ & $\begin{array}{c}\text { Charge } \\
\text { collection } \\
\text { efficiency } \\
\left(\eta_{\mathrm{c}}\right) \%\end{array}$ & $\begin{array}{c}\text { Effective } \\
\text { electron } \\
\text { diffusion } \\
\text { length }\left(\mathrm{L}_{\mathrm{f}}\right) \\
(\mu \mathrm{m})\end{array}$ & $\begin{array}{c}\text { Effective } \\
\text { electron } \\
\text { diffusion } \\
\text { Time } \\
\left(\tau_{\mathrm{D}}\right)(\mathrm{ms})\end{array}$ \\
\hline CdS type-a & 1.34 & 0.14 & 44 & 13.4 & 7.23 \\
CdS type-b & 3.23 & 1.09 & 90 & 32.3 & 0.91 \\
CdS type-c & 1.05 & 0.66 & 8.6 & 10.4 & 1.52 \\
\hline
\end{tabular}




\section{Conclusions}

Electron transport properties of three different $\mathrm{CdS}$ particles sensitized $\mathrm{ZrO} 2$ based QDSSC show that $\mathrm{CdS}$ type-b/ZrO $\mathrm{Zr}_{2}$ is a more active combination compared to $\mathrm{CdS}$ type-a and c. Optical absorption and surface morphologies of CdS type$\mathrm{b} / \mathrm{ZrO}_{2}$ are favorable for the electron regeneration and electron injections at the interface of polysulfide/ $\mathrm{CdS} / \mathrm{ZrO}_{2}$. The current density $\left(\boldsymbol{J}_{\boldsymbol{s c}}\right)$ for CdS type-b coated QDSSCs is 1.44 $\mathrm{mA} / \mathrm{cm}^{2}$. The measurements were recorded using $30 \mathrm{~mW}$ light source as an input power. Electron transport mechanism shows polysulfide prepared in distilled water based solvent is better electrolytes compared to methanol. Distilled water based polysulfide shows a higher solar cell efficiency $(1.0 \%)$ for $\mathrm{CdS}$ type-b sensitized $\mathrm{ZrO}_{2}$.

\section{Acknowledgments}

No funding information is available.

\section{Conflict of Interest}

There is no conflict of interest

\section{Supporting Information}

Not applicable.

\section{References}

[1] I. Robel, V. Subramanian, M. Kuno and P. V. Kamat, J. Am. Chem. Soc., 2006, 128, 2385-2393, doi:10.1021/ja056494n.

[2] N. Singh, R. M. Mehra, A. Kapoor and T. Soga, J. Renew. Sust. Ener., 2012, 4,013110, doi: 10.1063/1.3683531.

[3] D. K. Nandi and S. K. Sarkar, Energy Procedia.,2014, 54, 782-788, doi: 10.1016/j.egypro.2014.07.321.

[4] T. Uno, M. Koga, H. Sotome, H. Miyasaka, N. Tamai, Y. Kobayashi, J. Phys. Chem. Lett., 2018, 9, 7098-7104, doi: 10.1021/acs.jpclett.8b03106.

[5] H. K .Jun, M. A. Careem and A. K. Arof, Nanoscale Res. Lett., 2014, 9, 1-7, doi: 10.1186/1556-276X-9-69.

[6] V. Bhalekar, Prashant K. Baviskar, B. Prasad, N. Beedri, V. Kadam, H. M. Pathan, Chem. Phys. Lett., 2017, 689, 15-18, doi: 10.1016/j.cplett.2017.10.001.

[7] M. Copel, M. Gribelyuk, E. Gusev, Appl. Phys. Lett., 2000, 76, 436-438, doi: 10.1063/1.125779.

[8] S. Basahel, T. Ali, M. Mokhtar, K. Narasimharao, Nanoscale Res. Lett., 2015, 10, 73 doi: 10.1186/s11671-015-0780-z.

[9] K. S. Mohandas and D. Fray, Metall. Mater. Trans. B., 2009, 40, 685-699, doi: 10.1007/s11663-009-9263-x.

[10] E. Hao, H. Sun, Z. Zhou, J. Liu, B. Yang and J. Shen, Chem. Mater., 1999, 11, 3096-3102, doi: 10.1021/cm990153p.

[11] L. Borilo, L. Spivakova. Thin Films, 2012, 2, 119-124, doi: 10.5923/j.materials.20120204.04.

[12] M. Gratzel. Nature, 2001, 414, 338-344, doi: $10.1038 / 35104607$.

[13] S. Kokate, A. Supekar, P. Baviskar, B. Palve, S. Jadkar, K. Mohite, H. Pathan, Mater. Sci. Semiconductor Processing, 2018, 80, 179-183, doi: 10.1016/j.mssp.2018.02.033.

[14] Rajendra Prasad MB, Studies on factors influencing the performance of titania based quantum dot sensitized solar cell, (2016) Ph. D. Dissertation, Savitribai Phule Pune University.
[15] N. Soo, N. Prastomo, A. Matsuda, G. Kawamura, H. Muto, A. Mohd Noor, Z. Lockman and K. Cheong, Appl. Surf. Sci., 2012, 258, 5250-5258, doi: 10.1016/j.apsusc. 2012.02 .008

[16] J. Mosa, O. Fontaine, P. Ferreira, R. Borges, V. Vivierd, D. Grossoa, C. Roberta, C. Sanchez. Electrochim. Acta, 2011, 56, 7155-7162, doi: 10.1016/j.electacta.2011.05.074.

[17] L. Borilo and L. Spivakova, Am. J. Mater. Sci., 2012, 2, 119124, doi: 10.5923/j.materials.20120204.04.

[18] A. Emeline, G. Kataeva, A. Litke, A. Rudakova, V. Ryabchuk and N. Serpone, Langmuir, 1998, 14, 5011-5022, doi: 10.1021/la9800831.

[19] G. Herrera, N. Montoya, A. D.-Carbo and J. Alarcon, Phys. Chem. Chem. Phys., 2013, 15, 19312-19321, doi: 10.1039/C3CP53216J.

[20] M. Prasad, P. Tamboli, V. Bhalekar, V. Kadam, J. Abraham, C. Rajesh and H. M. Pathan, Mater. Res. Express, 2018,5, 066208 , doi: 10.1088/2053-1591/aacdb5.

[21] R. Ingle, A. Supekar, S. Sartale, P. Baviskar and H. Pathan, Opt., 2018, 161, 166-171 doi: 10.1016/j.ijleo.2018.02.038.

[22] S. Sarker, A. Ahammad, H. Seo, and D. Kim Intl. J Photoen., 2014,2014, 851705, doi: 10.1155/2014/851705.

[23] E. Barea, C. Zafer, B. Gultekin, B. Aydin, S. Koyuncu, S. Icli, F. Santiago, and J. Bisquert, J. Phys. Chem. C, 2010, 114, 19840 19848, doi: 10.1021/jp1055842.

[24] J. Bisquert and F. Fabreagat-Santiago. Impedance spectroscopy: a general introduction and application to dyesensitized solar cells in dye-sensitized solar cells, K. Kalyanasundaram, Ed., CRC; Taylor \& Francis, Boca Raton, Fla, USA (2010). P-457

[25] V. Jovanovski, V. Pedro, S. Gimnez, E. Azaceta, G. Cabanero, H. Grande, R. Zaera, I. Sero. and J. Bisquert, J. Am. Chem. Soc., 2011, 133, 20156-20159, doi: 10.1021/ja2096865.

[26] J Tian, G. Cao, Q. Zhang, Y. Li, J. Lan, X. Qu, G. Cao, J. Phys. Chem. C., 2012, 116, 18655-18662, doi: $10.1021 / \mathrm{jp} 3058838$.

[27] T Vossmeyer, L. Katsikas, M. Giersig, I. G. Popovic, K. Diesner, A. Chemseddine, A. Eychmuller, and H. Weller, $J$. Phy.Chem.,1994, 98, 7665-7673, doi: 10.1021/j100082a044.

[28] S. Keller, M. Spiegel, P. Fath, G. Willeke and E. Bucher, IEEE Trans. Electron Devices, 1998,45, 1569-1574.

Publisher's Note Engineered Science Publisher remains neutral with regard to jurisdictional claims in published maps and institutional affiliations. 